\section{Detection of Exceedingly Low Levels of HIV Proviral DNA in Multimillion Peripheral Blood Mononuclear Cells by PCR}

\author{
P.G. Babu, B.D. Rawal, \\ H. Khayam-Bashi, and \\ G.N. Vyas
}

Department of Laboratory Medicine, University of California, San Francisco, California 94143
Although the peripheral blood mononuclear cells (PBMCs) are the principal vectors of human immunodeficiency virus (HIV), infected cells range from 1 in 6,000-80,000 PBMCs in seropositive, asymptomatic individuals. ${ }^{(1)}$ The frequency of HIV-infected PBMCs is likely to be even lower in seronegative persons and demands the application of highly sensitive detection procedures.

In an earlier study we reported finding one positive culture result when we cocultured 1 million PBMCs pooled from 76,500 seronegative donors. ${ }^{(2)} \mathrm{Be}-$ cause the detection of HIV DNA after amplification via PCR is relatively more sensitive than HIV cocultures, we developed a novel PCR protocol, described below.

The conventional PCR protocol (micro PCR) uses only $100 \mu$ l of DNA-containing lysate, which is made from only 250,000 PBMCs. However, HIV DNA from $1 \times 10^{6}$ to $2 \times 10^{6}$ PBMCs has been amplified by PCR to detect between 1 and 10 copies of HIV in seropositive, asymptomatic individuals. ${ }^{(3)}$ We have developed a novel PCR procedure with a larger input of DNA obtained from the digestion and lysis of $50 \times 10^{6}$ PBMCs (macro PCR) as described here.

We spiked each of four tubes containing PBMCs $\left(50 \times 10^{6}\right)$ from HIV antibody-negative blood donors, with 10,1 , 0.1 , and $0.0 \mathrm{ACH}-2$ cells, which contain one copy of HIV DNA per cell. ${ }^{(4)}$ After washing the spiked PBMCs with phosphate-buffered saline, we centrifuged and resuspended the spiked PBMCs in $0.5 \mathrm{ml}$ of $\mathrm{AB}$ buffer [equal volumes of solution $\mathrm{A}, 0.1 \mathrm{M} \mathrm{KCl}, 0.01 \mathrm{M}$ Tris- $\mathrm{HCl}$,
$0.0025 \mathrm{M} \mathrm{MgCl}_{2} \cdot 6 \mathrm{H}_{2} \mathrm{O}$ (pH 8.3); and solution $\mathrm{B}, 0.01 \mathrm{M}$ Trizma base, $0.0025 \mathrm{M}$ $\mathrm{MgCl}_{2} \cdot 6 \mathrm{H}_{2} \mathrm{O}$ with $1 \% \mathrm{NP}-40,1 \%$ Tween 20 (pH 8.3) containing $300 \mu \mathrm{g}$ of proteinase K]. By holding the cells at $60^{\circ} \mathrm{C}$ for 1 hr followed by a 2 -hr hold at $95^{\circ} \mathrm{C}$, we inactivated proteinase $\mathrm{K}$. We used the lysate for PCR after adjusting the volume to $1.0 \mathrm{ml}$ with $\mathrm{AB}$ buffer and microcentrifuging at 12,000 rpm for $2 \mathrm{sec}$.

We observed PCR inhibition in preliminary experiments designed to amplify HLA-DQ- $\alpha$ sequences with lysates from $50 \times 10^{6}$ PBMCs in $1.0 \mathrm{ml}$ of PCR mixture containing $400 \mu \mathrm{g}$ of total DNA; however, we did not observe this inhibition when we used $12.5 \times 10^{6}$ cells $(100$ $\mu \mathrm{g}$ of total DNA). Consequently, we split the $1.0 \mathrm{ml}$ of lysate containing $400 \mu \mathrm{g}$ of total DNA into four equal aliquots of 250 $\mu l$ and then amplified the DNA therein using $1.0 \mathrm{ml}$ as the final volume of each PCR mix. Thus, we were able to amplify DNA from the entire sample of $50 \times 10^{6}$ PBMCs.

We added $250 \mu \mathrm{l}$ of the lysate to a $1.5-\mathrm{ml}$ polypropylene microcentrifuge tube containing $150 \mu \mathrm{l}$ of mineral oil, 20 $\mu l$ Taq buffer [500 $\mathrm{mm} \mathrm{KCl,} 100 \mathrm{~mm}$ Tris$\mathrm{HCl}(\mathrm{pH} 8.3), 20 \mathrm{mM} \mathrm{MgCl}_{2}$, and $0.1 \%$ gelatin], $4 \mu \mathrm{l}$ of HIV primers (SK38 and SK39, 200 pmoles each), $2 \mu$ l HLA-DQ- $\alpha$ primers (GH26 and GH 27, 2 pmoles each), $8 \mu$ l of dNTP mixture ( 4 dNTPs, 10 mM each), $4 \mu$ l of AmpliTaq polymerase (Cetus, $5 \mathrm{U} / \mu \mathrm{l}), 156 \mu \mathrm{l}$ of freshly deionized water, $540 \mu \mathrm{l}$ of $\mathrm{AB}$ buffer, and $10 \mu \mathrm{l}$ of $1.0 \mathrm{M} \mathrm{MgCl}_{2}$. After vortexing, we centrifuged the PCR mixtures at $12,000 \mathrm{rpm}$ for $2 \mathrm{sec}$. Because the total volume was $1.0 \mathrm{ml}$, the amplification could not be

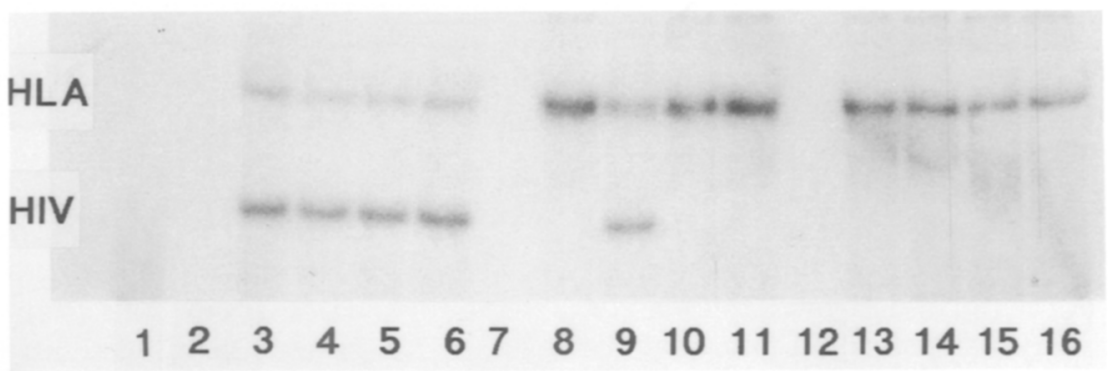

FIGURE 1 Sensitivity of macro PCR. Lysates from $50 \times 10^{6}$ PBMCs spiked with 10,1 , and 0.1 ACH-2 cells, respectively, were amplified in quadruplicates of $12.5 \times 10^{6}$ cells each. Following liquid hybridization using ${ }^{32} \mathrm{P}$-labeled probes SK19 and GH64 specific for HIV and HLA, respectively, and polyacrylamide gel electrophoresis, autoradiographs were prepared. (Lane 1) Reagent control; (lanes 3-6) $10 \mathrm{ACH}-2$ cells; (lanes 8-11) $1 \mathrm{ACH}-2$ cell; (lanes 13-16) $0.1 \mathrm{ACH}-2$ cell. Note that the HIV end point is detected in one of the quadruplicate aliquots from $50 \times 10^{6} \mathrm{PBMCs}$ spiked with one ACH-2 cell. HLA bands in lanes 3-6, 8-11 and 13-16 validate DNA amplification. Lanes 2,7 , and 12 were not loaded. 
TABLE 1 Comparison of Current (Macro) and Conventional (Micro) PCR for Detecting HIV DNA

\begin{tabular}{ccccccc}
\hline & Macro PCR mixture & & & \multicolumn{3}{c}{ Micro PCR mixture } \\
cells (no.) & vol $(\mu \mathrm{l})$ & HIV & & cells (no.) & vol $(\mu \mathrm{l})$ & HIV \\
\hline 250,000 & 1000 & + & & & \\
25,000 & 1000 & + & 50,000 & 100 & + \\
2,500 & 1000 & + & 5,000 & 100 & + \\
250 & 1000 & + & 500 & 100 & + \\
25 & 1000 & + & 50 & 100 & - \\
2.5 & 1000 & $+/-$ & & 5 & 100 & - \\
0.25 & 1000 & - & & 0.5 & 100 & - \\
0 & 1000 & - & & 0.5 & 100 & - \\
Endpoint for HIV/ml & & & & & \\
PCR mixture (cells) & & 25 & & & 5000 \\
\hline
\end{tabular}

performed in the conventional PerkinElmer DNA amplifier. Using a Biosycler oven (Bios Corporation, New Haven, CT) we amplified HIV DNA and HLA-DQ- $\alpha$ DNA over 30 cycles; each cycle provided denaturation at $95^{\circ} \mathrm{C}$ for $30 \mathrm{sec}$, primer hybridization at $55^{\circ} \mathrm{C}$ for $30 \mathrm{sec}$, and extension at $72^{\circ} \mathrm{C}$ for $60 \mathrm{sec}$. The final extension was performed at $72^{\circ} \mathrm{C}$ for 10 min. The supernatant obtained after a 2 -sec microcentrifugation at $12,000 \mathrm{rpm}$ of the amplified product yielded sufficient material for further processing to detect HIV-and HLA-specific markers by conventional methods. ${ }^{(5)}$ The negative control (Fig. 1, lane 1) contained the PCR reagents alone. Separate positive controls were not required in this experiment because we were testing PBMC populations that were spiked with known numbers of HIV-infected $\mathrm{ACH}-2$ cells.

In addition, we compared the sensitivity of our protocol with that of the conventional method using HIV-infected cells (Table 1). The end point sensitivity of HIV DNA detection by the macro and micro PCR protocols was 25 and 5000 cells $/ \mathrm{ml}$ in the respective PCR mixtures. Thus, by testing the lysate from 50 million cells, we have increased the probability of detecting HIV in seronegative individuals by 200 -fold. We detected HIV signals in all four aliquots of cell lysates, each of which contained an estimated $2.5 \mathrm{ACH}-2$ cells per $12.5 \times$ $10^{6}$ PBMCs. Thus, our protocol detected 10 copies of HIV in $50 \times 10^{6}$ PBMCs. In a total of 35 experiments, only one of the quadruplicate aliquots containing the lysate equivalent to an estimated one $\mathrm{ACH}-2$ cell in $12.5 \times 10^{6} \mathrm{PBMCs}$ showed the HIV signal (Fig. 1). We did not detect the HIV signal in lysates containing less than one (estimated) $\mathrm{ACH}-2$ cell per $50 \times$ $10^{6}$ PBMCs. Thus, we conclude that the detection limit of our protocol was between 1 and 10 copies of HIV per $50 \times$ $10^{6}$ PBMCs. Using this protocol we tested 141 pools of PBMCs with each pool containing a total of $50 \times 10^{6} \mathrm{PBMCs}$ pooled from 50 seronegative donors, and none showed the HIV DNA signal. We included a positive control containing lysate of $50 \times 10^{6}$ PBMCs that was spiked with $\sim 10 \mathrm{ACH}-2$ cells. Thus, by increasing the volume of individual PCR mixtures, our protocol effectively screened $50 \times 10^{6}$ million $\left(4 \times 12.5 \times 10^{6}\right)$ PBMCs from seronegative donor blood for HIV DNA. Although nonspecific amplification was not a problem, modification of the protocol to include the hot start technology ${ }^{(6)}$ may facilitate further the testing of even larger numbers of PBMCs. Our success with the quantitation of the PCR signal (Table 1) suggests that the protocol could be applied to quantitate the viral load in therapeutic efficiency trials. $^{(7)}$

\section{ACKNOWLEDGMENTS}

This research was supported by contract NO1-HB-86-7024 from the National Heart, Lung, and Blood Institute. We thank Dr. Michael P. Busch for supplying the ACH-2 cell line.

\section{REFERENCES}

1. Simmonds P., P. Balfe, J.F. Pentherer, C.A. Ludlam, J.O. Bishop, and A.J. LeighBrown. 1990. Human immunodeficiency virus-infected individuals contain provirus in small numbers of peripheral mononuclear cells and at low copy numbers. $J$. Virol. 64: 864-872.

2. Busch, M.P., E.B. Eble, H. Khayam-Bashi, D. Heilbron, E.L. Murphy, S. Kwok, J. Sninsky, H.A. Perkins, and G.N. Vyas. 1991. Evaluation of screened blood donations for human immunodeficiency virus type I infection by culture and DNA amplification of pooled cells. N. Engl. J. Med. 325: $1-5$.

3. Lee, T.-H., F.J. Sunzeri, L.H. Tobler, B.G. Williams, and M.P. Busch. 1991. Quantitative assessment of HIV-1 DNA load by coamplification of HIV-1 gag and HLADQ-alpha genes. AIDS 5: 1-9.

4. Clouse, K.A., D. Powell, I. Washington, G. Poli, K. Strebel, W. Farrar, P. Barstad, J. Kovacs, A.S. Fauci, and T.M. Folks. 1989. Monokine regulation of human immunodeficiency virus- 1 expression in a chronically infected human $\mathrm{T}$ cell clone. $J$. Immunol. 142: 431-438.

5. Erlich, H.A., D. Gelfand, and J.J. Sninsky. 1991. Recent advances in the polymerase chain reaction. Science 252: 1643-1651.

6. Chou, Q., M. Russell, D.E. Birch, J. Raymond, and W. Bloch. 1992. Prevention of PCR mis-priming and primer dimerization improves low copy number amplification. Nucleic Acids Res. 20: 1717-1723.

7. Coutlee, F., R.P. Viscidi, P. Saint-Antoine, A. Kessous, and R.H. Yolken. 1991. The polymerase chain reaction: A new tool for the understanding and diagnosis of HIV-1 infection at the molecular level. Mol. Cell. Probes 5: 241-259.

Received January 25, 1993; accepted in revised form May 21, 1993. 


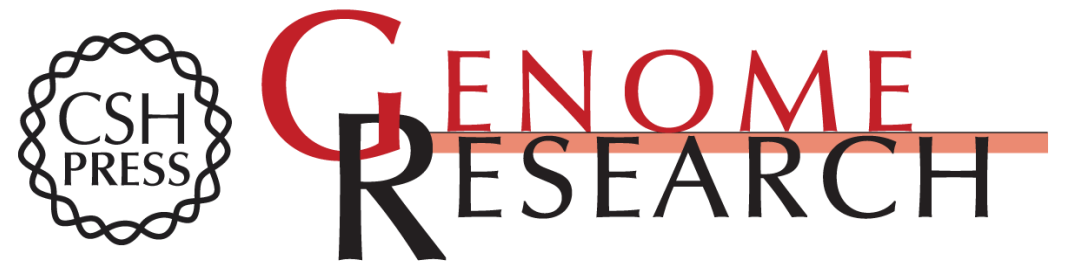

\section{Detection of exceedingly low levels of HIV proviral DNA in multimillion peripheral blood mononuclear cells by PCR.}

P G Babu, B D Rawal, H Khayam-Bashi, et al.

Genome Res. 1993 3: 63-64

References This article cites 7 articles, 3 of which can be accessed free at: http://genome.cshlp.org/content/3/1/63.full.html\#ref-list-1

License

Email Alerting

Receive free email alerts when new articles cite this article - sign up in the box at the Service top right corner of the article or click here.

\section{Affordable, Accurate} Sequencing.

To subscribe to Genome Research go to:

https://genome.cshlp.org/subscriptions 